\title{
Phytochemical, Nutritional and Antimicrobial Screening of Hexane, Ethyl Acetate and Ethanolic Extracts of Boswellia Dalzielii Leaves and Bark
}

\author{
Uzama Danlami $^{1}{ }^{\text {* }}$, Gbubele Joseph Daniel ${ }^{2}$, Bwai Machan David ${ }^{1}$, Kabir Musa Galadanchi ${ }^{3}$ \\ ${ }^{1}$ Chemistry Advanced Laboratory, Sheda Science and Technology Complex (SHESTCO), Abuja, Nigeria \\ ${ }^{2}$ Dept of Chemistry, Nasarawa State University, Keffi, Nigeria \\ ${ }^{3}$ Department of Chemistry, National Open University of Nigeria, Katsina, Nigeria
}

Email address:

uzamadan@yahoo.com (U. Danlami)

\section{To cite this article:}

Uzama Danlami, Gbubele Joseph Daniel, Bwai Machan David, Kabir Musa Galadanchi. Phytochemical, Nutritional and Antimicrobial Screening of Hexane, Ethyl Acetate and Ethanolic Extracts of Boswellia Dalzielii Leaves and Bar. American Journal of Bioscience and Bioengineering. Vol. 3, No. 5, 2015, pp. 76-79. doi: 10.11648/j.bio.20150305.19

\begin{abstract}
The objective of the study was to determine the medicinal values of Boswellia dalzielii plant by carrying out the proximate analysis, antimicrobial screening and phytochemical constituents of hexane, ethyl acetate and ethanolic extracts of the leaves and bark of the plant. Standard methods were used for the proximate and phytochemical screenings. Well diffusion method was applied for the antimicrobial screening of the extracts. The proximate analysis of the leaves shows; moisture $12.24 \%$, ash $7.43 \%$, crude fibre $32.85 \%$, crude lipids $20.41 \%$, crude protein $1.00 \%$ and carbohydrate $26.07 \%$ and that of the bark shows; moisture $8.51 \%$, ash $14.23 \%$, crude fibre $42.86 \%$, crude lipid $14.23 \%$, crude protein $0.40 \%$ and carbohydrate $19.56 \%$.The phytochemical screening of the leaves indicated the presence of tannins, cardiac glycosides, flavonoids, terpenoids, alkaloids and balsams while that of the bark indicated the presence of steroids, glycosides, alkaloids, terpenoids, flavonoids, and saponins. The antimicrobial screening of the leaves and bark extracts shows that they were active against Escherichia coli, Klebsiella pneumonia, Pseudomonas aeruginosa and Staphylococcus aureus.
\end{abstract}

Keywords: Boswellia Dalzielii, Well Diffusion, Proximate Analysis, Crude Protein, Cardiac Glycoside, Escherichia Coli

\section{Introduction}

In Africa and across the United States of America, herbal medicines represent the fastest growing segment of pharmacy trade, surely the cost of modern clinical medicines cannot be over looked, so most people consider other alternative form of medicines. Most herbal medicines are less expensive than prescription drugs [1]. Nature has been the source of medicine for thousands of years in the maintenance of human health since ancient time [2]. Over $50 \%$ of all modern clinical drugs are of natural product origin [3].

Boswellia dalzielii is a tree that belongs to the family of Burseraceae, from the genus of Boswellia and species of B. dalzielii. It is about $13 \mathrm{~m}$ high of the wooden savanna with a pale papery bark peeling and ragged characteristic. It is abundantly found in West Africa in countries such as Ghana, Niger, Ivory Coast, Upper Volta and Northern part of Nigeria, where the Hausa speaking people of Nigeria call it "Hano" or
"Ararrabi". The plant is popular in the Northern part of Nigeria due to its ethno medicinal importance. The extract from the leaves is used for the treatment of diarrhea in poultry. Both the root and the bark are used as an antidote for arrow poison. For example the root decoction of B. dalzielii and that of Daniella oliveri is used for wound healing [4]. The bark is eaten to induce vomiting and relieve symptoms of giddiness and palpitations. The bark contains a whitish exudate which secretes a fragrant that is burned to fumigate cloths and also act as deodorant for driving flies and mosquitoes from room [4]. The bark decoction is used as an antiseptic wash for sores in Ivory Coast and as an ingredient of a complicated prescription for leprosy. The bark is used in large quantity to make a wash of fever and rheumatism while it is also taken internally for gastro-intestinal troubles [5 - 7]. The aqueous extract of the stem bark produced an anti-ulcer activity and the oil from the leaves was found to exhibit significant activity against S. aureus, B. substilis and C. albican [8]. 
This work was aimed at carrying out the proximate, phytochemical and antimicrobial studies of the extracts of Boswellia dalzielii leaves and bark.

\section{Materials and Methods}

\subsection{Collection and Identification of Plant}

The plant was collected from Gudun Hausawa in Bauchi Local Government Area of Bauchi State, Nigeria in April 2014. The plant was identified and authenticated at Sheda Science and Technology Complex, Abuja, Nigeria.

\subsection{Preparation of Extracts}

The leaves and bark of the plant were air dried under shade for 6 weeks and powdered using wooden mortar and pestle. $120 \mathrm{~g}$ each of the powdered leaves and bark were taken and packed into a separate soxhlet extractor (each extractor for the leaves and bark respectively) and then extracted exhaustively with hexane first, followed by ethyl acetate and ethanol respectively for both the leaves and the bark. Each of the extract collected was concentrated using rotatory evaporator and then transferred to a water bath in order to evaporate the solvent. The concentrated extracts were transferred into a separate container corresponding to the solvent used, tightly covered and kept for further studies. The remaining powdered samples were used for the proximate analysis.

\subsection{Proximate Analysis}

The proximate evaluation for the moisture, ash, crude fibre, crude lipid, crude protein and carbohydrates was done using standard method [9- 11].

\subsection{Phytochemical Screening}

The qualitative screening for the presence of plant chemical constituents of Boswellia dalzielii was carried out on the extracts using standard procedure [12 - 14].

\subsection{Antimicrobial Screening}

The antimicrobial screening of the plant extracts was determined by using well diffusion method. Pure cultures of four bacteria (Escherichia coli, Klebsiella pneumonia, Pseudomonas aeruginosa and Staphylococcus aureus) were obtained from the microbiology laboratory, University of Abuja Teaching Hospital, Abuja, Nigeria.

Plates were prepared by pouring sterile Muller Hinton agar into sterile petri dishes that was previously autoclaved. Sterilized cotton swabs were dipped into the bacteria culture in nutrient bath and then swabbed on the agar plates. Wells of equal sizes were cut with proper graps in the medium and the extracts were added into it. The plates were incubated at 370 $\mathrm{C}$ for 24 hours. The standard drug used was streptomycin. At the end of the incubation period, inhibition zones were measured in millimeter. This study was carried out in triplicates.

\subsection{Statistical Analysis}

The experiments were carried out in triplicates and the results were expressed as mean \pm standard deviation.

\section{Results and Discussion}

\subsection{Phytochemical Screening}

The phytochemical screening of the leaves showed the presence of tannins, cardiac glycosides, flavonoids, terpenoids, alkaloids and balsams while that of the bark indicates the presence of steroids, glycosides, alkaloids, terpenoids, carbohydrates, flavonoids and saponins. It was reported that medicinal plants may contain many kinds of chemical components and their biological activities are not due to a single moiety [5]. The presence of these constituents gives an indication of the medicinal values of the leaves and the stem bark. Tannins are organic substances that produce astringent properties that hasten the healing of wounds and inflamed mucus membrane. Tannins also have the ability to decrease bacteria cell, proliferation by blocking key enzymes of microbial metabolism. Flavonoids have been found to possess antimicrobial properties [15], antioxidant [16] and anti-tumour [17, 18] effect, which are associated with free radical scavenging action. Alkaloids have physiological effect especially on the nervous system [19]. Cardiac glycosides stimulate the heart in case of heart failure [20]. The presence of these constituents in the leaves and bark of Boswellia dalzielii suggests that the plant is pharmacologically active, thus supporting the claims by traditional healers.

Table 1: The phytochemical screening of the hexane, ethyl acetate and ethanol extracts of the leaves and bark of Boswellia dalzielii.

\begin{tabular}{lll}
\hline & Leaves extracts & Bark extracts \\
\hline $\begin{array}{l}\text { Chemical } \\
\text { constituents }\end{array}$ & $\begin{array}{l}\text { Hexane Ethyl acetate } \\
\text { Ethanol }\end{array}$ & $\begin{array}{l}\text { Hexane Ethyl acetate } \\
\text { Ethanol }\end{array}$ \\
\hline Tannins & +-+ & --+ \\
Steroids & --+ & +-+ \\
Triterpenoid & -+- & -+- \\
Glycosides & --- & -++ \\
Phenols & --- & --- \\
Alkaloids & +++ & +++ \\
Terpenoids & +-+ & +-+ \\
Carbohydrates & -- & --+ \\
Flavonoids & --+ & +-+ \\
Cardiac glycosides & +++ & ++- \\
Resins & -- & -- \\
Balsams & --+ & -+ \\
Saponin & -- & -+ \\
\hline
\end{tabular}




\subsection{Proximate Analysis}

The proximate evaluation conducted on the powdered leaves and bark of Boswellia dalzielii revealed that the ash content of the bark is higher than that of the leaves, therefore the bark contains more inorganic constituents than the leaves. The result also showed that the crude lipid and the crude protein content of the leaves was higher than that of the bark which indicated that the leaves contain more calories constituent than the bark. The crude fibre content of the bark was higher than that of the leaves, therefore it may provide higher protection against gastrointestinal disease than the leaves. Looking also at the result, it showed that carbohydrate content of the leaves which, is an important source of energy is higher than that of the bark.

Table 2: The proximate analysis of the leaves and stem bark of Boswellia dalzielii.

\begin{tabular}{ll}
\hline & Values $(\mathbf{\%})(\mathbf{n}=\mathbf{3})$ \\
\hline Parameter & Leaves Bark \\
\hline Moisture & $12.24 \pm 0.098 .51 \pm 0.23$ \\
Ash & $7.42 \pm 0.1414 .23 \pm 0.19$ \\
Crude fibre & $32.85 \pm 0.4242 .86 \pm 0.41$ \\
Crude lipid & $20.41 \pm 0.5314 .42 \pm 0.11$ \\
Crude protein & $1.00 \pm 0.400 .40 \pm 0.05$ \\
carbohydrate & $26.07 \pm 0.5419 .56 \pm 0.10$ \\
\hline
\end{tabular}

\subsection{Antimicrobial Activities}

Antimicrobial properties of medicinal plants are being studied in various part of the world. The World Health Organization estimated that plant extracts or their active constituents are used as folk medicine in traditional therapies of $80 \%$ of the world population. In this work, most especially the ethyl acetate and ethanol extracts of both the leaves and bark show activity against the test organisms. The result shows that the ethyl acetate and ethanol extracts of both the leaves and bark of Boswellia dalzielii were found to be more active against the test organisms than that of the hexane extract. The results also showed that the activity of the test organisms in both ethyl acetate and ethanol extracts showed significant antimicrobial activities at higher concentration most especially in Escherichia coli and Klebsiella pneumonia test organisms. It was also seen that the ethyl acetate and ethanol extracts of the leaves were more active against the test organisms at higher concentration than that of the bark. The higher antimicrobial activity in the ethyl acetate and ethanol extracts of both the leaves and bark may be due to the presence of chemical constituents such as tannins, flavonoid, steroids and terpenoids. These medicinal bioactive components exert antimicrobial activity through different mechanisms. Steroids are known for their antibacterial activity especially associated with membrane lipids and causes leakage from liposomes. Flavonoids which have been found to be an effective antimicrobial substance against microorganisms. Tannins causes inhibition in cell wall synthesis by forming irreversible complexes with prolene rich protein. Terpenoids are responsible for dissolution of the cell wall of microorganism by weakening the membranous tissues.

Table 3: The antimicrobial activity of the extracts of leaves and bark of Boswellia dalzielii.

\begin{tabular}{lccccc}
\hline $\begin{array}{l}\text { Test Ethyl acetate extract of the leaves } \\
\text { organisms }\end{array}$ & $\mathbf{5 0 0} \mathbf{m g} \backslash \mathbf{m l}$ & $\mathbf{2 5 0} \mathbf{m g} \backslash \mathbf{m l}$ & $\mathbf{1 2 5} \mathbf{m g} \backslash \mathbf{m l}$ & $+\mathbf{v e}$ & -ve \\
\hline $\begin{array}{l}\text { Escherichia } \\
\text { coli }\end{array}$ & $21.0 \pm 0.0$ & $16.0 \pm 0.0$ & $11.5 \pm 0.5$ & $28.0 \pm 0.0$ & NA \\
$\begin{array}{l}\text { Klebsiella } \\
\text { pneumonia }\end{array}$ & $23.6 \pm 0.0$ & $20.0 \pm 0.0$ & $16.5 \pm 0.5$ & $30.0 \pm 0.0$ & NA \\
$\begin{array}{l}\text { Pneudomonas } \\
\text { aeruginosa }\end{array}$ & $17.5 \pm 0.5$ & $11.0 \pm 0.0$ & $9.5 \pm 0.5$ & $28.0 \pm 0.0$ & NA \\
$\begin{array}{l}\text { Staphylococcus } \\
\text { aureus }\end{array}$ & $25.5 \pm 0.5$ & $20.0 \pm 0.0$ & $15.5 \pm 0.5$ & $32.0 \pm 0.0$ & NA \\
\hline
\end{tabular}

(b)Ethyl acetate extract of the bark

\begin{tabular}{lccccc}
\hline $\begin{array}{l}\text { Test } \\
\text { organisms }\end{array}$ & $\mathbf{5 0 0} \mathbf{m g} \backslash \mathbf{m l}$ & $\mathbf{2 5 0} \mathbf{m g} \backslash \mathbf{m l}$ & $\mathbf{1 2 5} \mathbf{m g} \backslash \mathbf{m l}$ & $+\mathbf{v e}$ & -ve \\
\hline $\begin{array}{l}\text { Escherichia } \\
\text { coli }\end{array}$ & $20.0 \pm 0.0$ & $20.0 \pm 0.0$ & $8.5 \pm 0.5$ & $28.0 \pm 0.0$ & $\mathrm{NA}$ \\
$\begin{array}{l}\text { Klebsiella } \\
\text { pneumonia }\end{array}$ & $21.0 \pm 0.0$ & $19.0 \pm 0.0$ & $14.0 \pm 0.0$ & $30.5 \pm 0.0$ & $\mathrm{NA}$ \\
$\begin{array}{l}\text { Pneudomonas } \\
\text { aeruginosa }\end{array}$ & $15.5 \pm 0.5$ & $13.0 \pm 0.0$ & $10.5 \pm 0.5$ & $30.0 \pm 0.0$ & $\mathrm{NA}$ \\
$\begin{array}{l}\text { Staphylococcus } \\
\text { aureus }\end{array}$ & $21.0 \pm 0.0$ & $20.5 \pm 0.0$ & $19.0 \pm 0.0$ & $31.0 \pm 0.0$ & $\mathrm{NA}$ \\
\hline
\end{tabular}

(c)Hexane extract of leaves

\begin{tabular}{|c|c|c|c|c|c|}
\hline $\begin{array}{l}\text { Test } \\
\text { organisms }\end{array}$ & $500 \mathrm{mg} \backslash \mathrm{ml}$ & $250 \mathrm{mg} \backslash \mathrm{ml}$ & $125 \mathrm{mg} \backslash \mathrm{ml}$ & $+\mathbf{v e}$ & -ve \\
\hline $\begin{array}{l}\text { Escherichia } \\
\text { coli }\end{array}$ & $9.0 \pm 0.0$ & NA & NA & $28.0 \pm 0.0$ & NA \\
\hline $\begin{array}{l}\text { Klebsiella } \\
\text { pneumonia }\end{array}$ & NA & NA & NA & $30.0 \pm 0.0$ & NA \\
\hline $\begin{array}{l}\text { Pneudomonas } \\
\text { aeruginosa }\end{array}$ & $9.5 \pm 0.5$ & NA & NA & $30.0 \pm 0.0$ & NA \\
\hline $\begin{array}{l}\text { Staphylococcus } \\
\text { aureus }\end{array}$ & NA & NA & NA & $32.0 \pm 0.0$ & NA \\
\hline
\end{tabular}

(d)Hexane extract of the bark

\begin{tabular}{|c|c|c|c|c|c|}
\hline $\begin{array}{l}\text { Test } \\
\text { organisms }\end{array}$ & $500 \mathrm{mg} \backslash \mathrm{ml}$ & $250 \mathrm{mg} \backslash \mathrm{ml}$ & $125 \mathrm{mg} \backslash \mathrm{ml}$ & + ve & -ve \\
\hline $\begin{array}{l}\text { Escherichia } \\
\text { coli }\end{array}$ & $10.0 \pm 0.0$ & $9.0 \pm 0.0$ & NA & $27.0 \pm 0.0$ & NA \\
\hline $\begin{array}{l}\text { Klebsiella } \\
\text { pneumonia }\end{array}$ & $9.0 \pm 0.0$ & NA & NA & $30.0 \pm 0.0$ & NA \\
\hline $\begin{array}{l}\text { Pneudomonas } \\
\text { aeruginosa }\end{array}$ & $9.0 \pm 0.0$ & NA & NA & $30.0 \pm 0.0$ & NA \\
\hline $\begin{array}{l}\text { Staphylococcus } \\
\text { aureus }\end{array}$ & NA & NA & NA & $32.5 \pm 0.0$ & NA \\
\hline \multicolumn{6}{|c|}{ (e)Ethanol extract of the leaves } \\
\hline $\begin{array}{l}\text { Test } \\
\text { organisms }\end{array}$ & $500 \mathrm{mg} \backslash \mathrm{ml}$ & $250 \mathrm{mg} \backslash \mathrm{ml}$ & $125 \mathrm{mg} \backslash \mathrm{ml}$ & + ve & -ve \\
\hline $\begin{array}{l}\text { Escherichia } \\
\text { coli }\end{array}$ & $24.0 \pm 0.0$ & $20.0 \pm 0.0$ & $17.5 \pm 0.5$ & $29.0 \pm 0.0$ & NA \\
\hline $\begin{array}{l}\text { Klebsiella } \\
\text { pneumonia }\end{array}$ & $26.0 \pm 0.0$ & $23.5 \pm 0.5$ & $20.0 \pm 0.0$ & $30.0 \pm 0.0$ & NA \\
\hline $\begin{array}{l}\text { Pneudomonas } \\
\text { aeruginosa }\end{array}$ & $21.0 \pm 0.0$ & $16.5 \pm 0.5$ & $11.0 \pm 0.0$ & $29.0 \pm 0.0$ & NA \\
\hline $\begin{array}{l}\text { Staphylococcus } \\
\text { aureus }\end{array}$ & $16.0 \pm 0.0$ & $14.5 \pm 0.5$ & $10.0 \pm 0.0$ & $32.0 \pm 0.0$ & NA \\
\hline
\end{tabular}




\begin{tabular}{|c|c|c|c|c|c|}
\hline $\begin{array}{l}\text { Test } \\
\text { organisms }\end{array}$ & $500 \mathrm{mg} \backslash \mathrm{ml}$ & $250 \mathrm{mg} \backslash \mathrm{ml}$ & $125 \mathrm{mg} \backslash \mathrm{ml}$ & $+\mathrm{ve}$ & - ve \\
\hline $\begin{array}{l}\text { Escherichia } \\
\text { coli }\end{array}$ & $20.0 \pm 0.0$ & $18.0 \pm 0.0$ & $15.5 \pm 0.5$ & $29.0 \pm 0.0$ & NA \\
\hline $\begin{array}{l}\text { Klebsiella } \\
\text { pneumonia }\end{array}$ & $23.5 \pm 0.5$ & $23.0 \pm 0.0$ & $18.5 \pm 0.5$ & $30.0 \pm 0.0$ & NA \\
\hline $\begin{array}{l}\text { Pneudomonas } \\
\text { aeruginosa }\end{array}$ & $19.0 \pm 0.0$ & $17.5 \pm 0.5$ & $13.5 \pm 0.5$ & $29.5 \pm 0.0$ & NA \\
\hline $\begin{array}{l}\text { Staphylococcus } \\
\text { aureus }\end{array}$ & $12.5 \pm 0.0$ & $12.0 \pm 0.0$ & $8.5 \pm 0.0$ & $31.0 \pm 0.0$ & NA \\
\hline
\end{tabular}

$\mathrm{NA}=$ Non active.

\section{Conclusion}

From the results of the proximate, phytochemical and antimicrobial screening of the leaves and bark of Boswellia dalzielii, the study justifies the use of the leaves and bark of the plant in traditional medicine for the treatment of various diseases caused by microbes.

\section{References}

[1] Baker, J. T; Borris, R. P; Carte, B; Cordell, G.A; Soejarto, D. D; Cragg, G. M; Gurpa, M. P; Madulid, D. A and Tyler, V. E. J. Natural product drug discovery and development: New perspective on international collaboration. J. Nat prod, 1995; 58:1325-1357.

[2] Farombi, E. O. Africa indigenous plants with chemotherapeutic potential biotechnological approach to the production of bioactive prophylactic agent. Africa J. Biotech. 2003; 2:667-671.

[3] Stuffness, M and Dourous, J. Current status of the NCI plant and animal product program. J Nat Prod. 1982; 45:1-14.

[4] Etuk, E. U; Agaiw, B. W; Onyeyili, P. A and Ottah C. U. Toxicology studies of the aqueous stem bark of Boswellia dalzielii in albino rats. Indian Journalof pharmacology. 2006; 38:359-360.

[5] Choi, E. J; Yakozawa, T; Rhyu, D. Y; Kim, S. C; Shibahara, N and Park, J. C. Study on the inhibitory effects of Korean medicinal plants and their main compound on 1,1-diphenyl-2picrylhydrazl radical. Phytomed, 2003; 10:544-551.

[6] Oliver, B. Medicinal plants in Nigeria. Nigeria College of Arts, Science and Technology, Ibadan, Nigeria. 1960; pp 49-50.

[7] Burkill, H. M. Useful plants of West Tropical Africa. Vol 1, Royal Botanical Garden Kew, 1985; pp 300.
[8] Nwinyi, F. C; Binda, L.; Ajoku, G. A; Ariagu, S. O. and Gamaniel et al., Evaluation of the aqueous extract of Boswellia dalzielii stem bark for antimicrobial activities and gastrointestinal effects. Afri. J. Biotechnol. 2004; 3:284-288.

[9] Udo, E. J and J. A Oguwele, Laboratory manuel for the analysis of soil, plants and water samples. 3rd Edition, department of crop production, university of Ilorin, Kwara state Nigeria. 1986; pp 131-152.

[10] James, C. S. Analytical Chemistry of Food. Champman and Hall, London, 1995; pp 64-65.

[11] AOAC. Official Methods of Analysis. 4th Edition, Association of Official Analytical Chemists, Washington DC. 1990.

[12] Debela, A. Manual for phytochemical screening of medicinal plants. Ethopian Health and Nutrition Research Institute, Addis Ababa, Ethopia. 2002; pp 35-47.

[13] Sofowora, A. Screening plants for bioactive agents. In: Medicinal plants and traditional medicinal in Africa. 2nd Edition. Spectrum books Ltd. 1993; pp 134-156.

[14] Trease, G. E and W. C Evans. Pharmacognosy. 15th Edition. publishers, London, 2002; pp 42-44, 221-229, 246-249, 304306, 331-332, 391-393.

[15] Navayana, K. R; Reddy, M. S; Chaluvadi, M. R and Krishma, D. R. Bioflavonoids classification, pharmacology, biochemical effects and therapeutic potential. Indian J. Pharmacol. 2001; 33:2-16.

[16] Robak, J and Mareinkiewiez, E. Scavenging of oxygen species as the mechanism of drugs action. Pol. J. Pharmacol. 1995; 47:89-98.

[17] Castello, M. H; Perkin, E; Cambell, J. H; Doerr, R; Hassett, J. M; Kandaswani, C and Meddleton Jr, E. The effect of bioflavonoids quercetin on squamous cell carcinoma of head and neck region. Am J. Surg. 1989; 158:351-355.

[18] Inoue, T and Jackson, E. K. Strong antiproliferative effects of baicalein in cultured rat hepatic stallate cell. Eur. J. pharmacol. 1999; 378:129-135.

[19] Shaheen, H. M; Ali, B. H; Alqurawi, A. A and Bashir, A. K. Effect of Psidium guajava leaves on some aspect of central nervous system in mice. Phytother Res; 2000; 14:107-111.

[20] Olukemi, M. A; Kandakai, Y. T. - Olukemi and Mawak, J. D. Antibacterial activity of the stem bark of Boswellia dalzielii. J. Pharmacy Bioresource.2005; 2:131-136. 